International Journal of Linguistics, Literature and Translation

ISSN: 2617-0299 (Online); ISSN: 2708-0099 (Print)

DOI: 10.32996/ijlt

Journal Homepage: www.al-kindipublisher.com/index.php/ijltt

IJLLT

\title{
Teaching Speaking and Listening Skills through Audio-Lingual Versus Conventional Methods of Instruction: Which Method Is More Effective?
}

\author{
Fatemeh Ebrahimi ${ }^{1} \square$ and Maryam Elahifar ${ }^{2}$ \\ ${ }^{12}$ Department of English Language Teaching, Ahvaz Branch, Islamic Azad University, Ahvaz, Iran \\ $\square$ Corresponding Author: Fatemeh Ebrahimi, E-mail: moonlight.night1@yahoo.com
}

\begin{abstract}
ARTICLE INFORMATION ABSTRACT
\end{abstract}
Received: 22 September 2021

Accepted: 14 October 2021

Published: 30 November 2021

DOI: 10.32996/ijllt.2021.4.11.8

\section{KEYWORDS}

Audio-Lingual method, traditional instruction, listening skill, speaking skill.
The goal of this study was to check the impact of the Audio-Lingual Method (ALM) compared to traditional training on enhancing intermediate EFL learners' listening and speaking abilities. An Oxford Quick Placement Test was given to 105 participants to meet the study's goals, and 78 participants were chosen in the end. They were then randomly assigned to the control group (CG) and the experimental group (EG). Validated listening and speaking tests were given to them as a pre-test before they began treatment. The EG subsequently started treatment, which included teaching and learning listening and speaking skills through ALM. At the same time, the CG received traditional training, which included instruction based on the teacher's instances and exercises. The two groups were given the identical listening and speaking test as the post-test after 20 sessions of treatment. In addition, after the post-test was administered, a questionnaire comprising twelve items was distributed among 15 teachers teaching at different institutes to seek their views and perspectives regarding the application of ALM in teaching listening and speaking skills. Paired and Independent Samples t-tests were used to assess the data. The results revealed that the EG outperformed the CG by a substantial margin. The EG outperformed the CGs in both skills. The findings imply that ALM may be utilized in English classes to help EFL students improve their listening and speaking abilities.

\section{Introduction}

Learning a language is primarily learning the four basic skills of listening, speaking, reading, and writing. It's not just about imparting knowledge and information, as it is in the case of other topics. It's a multi-step procedure (Bashir, Azeem, \& Dogar, 2011). Spoken language is a unique occurrence since it is a naturally occurring phenomenon. Teaching a spoken language that is not one's primary language is a time-consuming and challenging endeavor. Proper technique, processes, drill, and a sample of the target language are required. To establish a linguistic atmosphere, the instructor must employ unique strategies appropriate for students' mental levels and educational devices. Given the importance of speaking and listening skills, there is always a need to use a proper teaching approach for progressing these two abilities.

The ALM is founded on the behaviorist approach, which holds that some features of living creatures, such as people, can be learned through a reinforcement system in which the correct use of a property is learned with positive feedback and incorrect usage is punished. ALM supporters argue that children should be taught a language directly, rather than utilizing their mother language to clarify new terms or grammatical principles. Instructors would use the ALM to give proper sentence models to pupils, who would then have to regurgitate them. Instructors would then extend the process by providing learners new words to try out in structures (Larsen-Freeman, 2000; Shafiee, Mobini, Namaziandost, \& Ghodoosi, 2020). There is no explicit grammar teaching in audiolingualism; instead, everything is memorized in its original form. The goal is to train pupils to practice specific structures until they can utilize them on their initiative.

Consequently, classes are constructed around static drills in which students have little or no influence over the output they produce independently. Teachers are not responding in a way that will lead to negative feedback from students. To lay the groundwork for

Copyright: (c) 2021 the Author(s). This article is an open access article distributed under the terms and conditions of the Creative Commons Attribution (CC-BY) 4.0 license (https://creativecommons.org/licenses/by/4.0/). Published by Al-Kindi Centre for Research and Development, London, United Kingdom. 
language learning, this form of activity is opposed to communicative language education (Namaziandost \& Imani, 2020; Wang, 2009).

When it comes to audio-lingual activities, Brown (2001) explains that learners are required to listen, recite, and retain a wide range of conversations (Brown, 2001). As a result, dialogues are essential. They show students how to use various patterns and structures in real-life situations in the target language, such as greetings, approval or disapproval, opinion exchange of information, or discussion of standard topics. They do this by illustrating common social situations (weather, hobbies, etc.). This genuinely aids learners in determining which phrase is most appropriate for a given situation. Students should practice accurate pronunciation, intonation, stress, and rhythm by rehearsing and remembering the entire dialogue or at least some select segments of it as part of the ALM. ALM emphasizes the habit-formation model of learning, which is well-suited to the use of mimicking drills and recurrence, according to Brown (2001).

Methods are a practical embodiment of an approach in English language education, and they play a significant part in assisting students in learning a second/foreign language or improving their communication skills. ALM is one of these strategies that is frequently employed in the field of English language acquisition. Overall, English is seen as a foreign language in Iran because it is not used as a common medium of communication. Instead, it is employed for international commerce and communications. Even though English has been made mandatory for all Iranian students to learn from elementary school to university, they have failed to improve their English competence, particularly in listening and speaking. This failure can be attributed to difficulties in English language instruction (Namaziandost, Shafiee, \& Ziafar, 2020).

These issues include 1) a scarcity of trained teachers, 2) a lack of passion in the classroom, 3) a scarcity of standardized textbooks, 4) a scarcity of teaching resources, and 5) a scarcity of a standard curriculum, among others. Furthermore, one of the most significant deficits is that the majority of teachers lack adequate understanding of numerous methodologies and the necessary skills to put them into practice. Teachers do not engage pupils in classroom activities that encourage them to be more committed to learning English. The result is that kids get apprehensive about the work of learning. As a result, if teachers just examine cognitive concerns while developing their instructional methods, they will overlook the psychological aspects of human behavior. As a result, language teachers must be aware of their students' psychological states (motivation and needs) to comprehend the affective conditions necessary for learning. Teaching foreign languages in Iran appears to have been out of date for a long time. Regardless of whether or not more contemporary procedures are employed, traditional methods are still in use (Shakibaei, Shahamat, \& Namaziandost, 2019). It is worth noting that the methods employed in Iranian schools or educational settings to teach English do not engage students or encourage them to participate in class activities; these approaches are primarily of the grammar-translation variety, and therefore should be avoided. Because of this, it is vital to monitor how our pupils learn a language and then evaluate which teaching approaches provide the best outcomes for them based on what has been learned. For students, audio-lingualism is one of the most effective languages teaching methods due to the requirement of listening and speaking instruction in the language lab and the nature of Iran, which necessitates presenting such vocabulary and correct language patterns in a systematic and motivational manner. Students will watch CDs and work in repetition in drills and dialogs based on real-life situations, with positive reinforcement from the instructor, when this teaching method is used. The instructor will be able to maintain control of the class. This will assist students in becoming more motivated to study the language and attain comprehension and production at the desired level as they progress through the program (Namaziandost, Hashemifardnia, \& Shafiee, 2019).

Reviewing the literature so far, the impact of different methods of instruction in the language learning process, especially in the ALMian context, did not receive enough attention it deserves. Moreover, rare studies in ALM have been done in this regard. Thus, this study was conducted to investigate the impact of audio-lingual versus conventional methods of instruction on EFL learners' developing speaking and listening skills. Accordingly, the following research questions were raised in this study:

1. Does the implementation of the ALM have a significant impact on the listening and speaking skills of Iranian EFL learners?

2. Is there any significant difference between intermediate EFL learners who use the ALM method in learning listening and speaking with the traditionally taught learners?

3. Do $L 2$ teachers have a positive attitude towards the application of ALM in teaching listening and speaking skills?

Consequently, this study is based on the following null hypotheses:

H0.1. The implementation of the ALM has does not have a significant impact upon the listening and speaking skills of Iranian EFL learners.

H0.2. There is no significant difference between intermediate EFL learners who use the ALM method in learning listening and speaking with the traditionally taught learners.

H0.3. L2 teachers do not have a positive attitude towards the application of ALM in teaching listening and speaking skills. 


\section{Literature Review}

As Nunan (2003) points out, speaking is challenging and inherence to skills in learning a foreign language. As explained by Hedge (1993), the term "fluency" has two meanings: "the ability to link units of speech together with ease and without strain, improper slowness, or unnecessary hesitation...and... natural language use" (p. 275). Gilbert (1995) feels that accurate pronunciation is essential for successful listening comprehension. The hearer is critical; if they cannot hear clearly and quickly understand what is being said, they will become lost in the dialogue with the target speaker. Then there's the fact that hearing content is extremely crucial in all parts of language learning, especially in terms of oral communication skills. According to Cameron (2001), "Speaking is the active use of language to express meanings for other people to understand them" (p. 40). Aside from the traditional grammatical and semantic principles, those who are teaching or learning to speak must also absorb information about how native speakers use language in the context of structured interpersonal exchange (Richards \& Rodgers, 2002; Namaziandost, Homayouni, \& Rahmani, 2020). According to Lingzhu (2003) and Ziafar and Namaziandost (2019), top-down is very important for the listening process. Then extra listening is a beneficial strategy for speaking proficiency (fluency or accuracy).

According to Brown (2001), audio-lingual exercises are provided not only in drill short patterns but also in a variety of dialogues, which students must listen to, repeat, and recall, as well as in drill short patterns (Brown, 2001; Namaziandost, Neisi, \& Banari, 2019). Dialogs are therefore critical in that they provide students with the proper structure as well as an understanding of how to use the various types of patterns inappropriate situations because dialogues usually illustrate socio-cultural concerns of the target language, i.e., speech acts such as greetings and expressing approval or disapproval, opinion exchanges, or discussion of standard topics (weather, hobbies, etc.). This genuinely aids kids in recognizing which speech is appropriate for the situation they are in. Apart from that, by repeating and memorizing the entire dialogue or at least some key passages, learners in the ALM should pay close attention to the correct pronunciation, intonation, stress, and rhythm patterns. ALM emphasizes the habit-formation model of learning, according to Brown (2001), which is entirely compatible with mimicking drills and repetition and other instructional strategies.

The term "listening" refers to "the practice of paying attention to and attempting to make sense of something we hear ( $p .12)$," as defined by Underwood (1989). According to Mendelsohn (1994), listening comprehension is defined as the ability to comprehend the spoken language of native speakers. According to O'Malley, Chamot, and Kupper (1989), listening comprehension is an active and conscious process in which the listener generates meaning by using signals from contextual information and current knowledge while relying on numerous strategic resources to complete the task need.

According to Brown (1994), teaching listening skills using ALM improves the students' listening skills because (1) new material is presented in dialog form, (2) there is reliance on mimicry, memorization of set phrases, and overlearning, (3) there is a strong emphasis on active listening, and (4) there is a strong emphasis on active listening during the course. The contrastive analysis method is used to sequence the structures, which are then taught one by one. (4) Repetitive drills are used to teach structural patterns. (5) There is little or no grammatical justification for the statement. Grammatical concepts are taught using inductive analogy rather than reasoned explanation, (6) vocabulary is rigorously constrained, and students learn vocabulary in context, and a great deal of emphasis is placed on using recordings, language lab sessions, and visual aids. A great deal of emphasis has been placed on pronunciation. (8) (9) Teachers are only permitted to use a limited amount of their native language. The reinforcement of successful reactions occurs immediately after they occur. The goal is to have pupils make utterances free of errors, and there is much effort put forward in this direction. The inclination is to modify language while ignoring the content of the message (12).

Prayoga (2012) attempted to study the effectiveness of the audio-lingual method in teaching listening skills to first-grade students enrolled in the Asrama Bengkel Bahasa course." According to the author, quantitative research was employed in this study, aiming to evaluate hypotheses with the help of objective instruments and statistical analysis. "Quantitative research methods are used to evaluate a question on which an answer might be based by gathering and statistically evaluating data that is presented in the numerical form" (Crowl, 1996, P.10). The results of the data analysis showed that teaching listening skills using ALM improved students' listening ability in the first grade of the Asrama Bengkel Bahasa Course.

Adult English language learners were taught speaking skills by Kunnu and Sukwises (2014) using ALM. However, it should be noted that this research was conducted under the assumption that ALM would resolve Iranian learners' English-language difficulties. It is planned to divide the findings of this study into three categories, which will be discussed as follows: Participants can apply the knowledge gained from the model dialogue to a real-world issue in the classroom, as demonstrated in 1 . The participants will require assistance from the teacher at the outset if they run into any difficulties. 2. Participants can communicate more fluently and confidently in English as a result of this course. 3. After each session, the writer can see that they make an effort to communicate with the teacher in English. It was discovered from the findings of this study that participants can adjust their knowledge to practice having a conversation with others. As demonstrated in this experiment, learners do not learn by imitation and repetition. Those 
who use them can elicit commonplace dialogue. Using what they have learned, the participants mimic the teacher. They pay close attention to what is being said in the discussion. The author believes that Thais possess core English capabilities; yet, they cannot communicate effectively due to a lack of oral communication abilities.

The researches reviewed above revealed that learning through ALM is vital for students to improve their language proficiency. The mentioned studies also indicated that ALM has positive effects on learning skills and sub-skills of the language. However, the impact of ALM versus traditional instruction on Iranian EFL learners' speaking and listening skills has not been investigated so far. This study opens a window to fill out this gap.

\section{Methods}

\subsection{Participants}

Among 105 participants, 78 intermediate English as a foreign language student from a private English language institute in Iran were chosen. They were male university students between the ages of 19 and 21 . All participants were divided into two groups by chance: the CG (which had 39 learners) and the EG (which contained 39 participants). The classes were held twice a week in the afternoon, for a total of around 70 minutes each session.

\subsection{Instrumentation}

The following instruments were used to collect the data in this study.

\subsubsection{Pre-test}

A pre-test of listening and speaking was administered to the participants before the start of the study, and the results were adapted from Haq's (2014) test. This exam was carried out on the mental level to determine whether or not the test subjects were comparable. Both listening and speaking components were required for the test. In this exercise, students were required to listen to a text before asking questions linked to the reading. Speaking was the focus of the second segment. To assess their public speaking abilities, learners were asked questions. With the pre-test, the instructors wanted to see how students were doing on their present assignments. Aside from that, the students' speaking pre-test was divided into three sections, each of which covered a different subject matter. Questions concerning family, employment, and school were included in the first section of the test. Another aspect of the second section was to describe someone or something. Finally, there was a broad discussion about a topic in the final section of the presentation. The inter-rater reliability of the test was determined, and the result was 0.989 , which indicates that the test is reliable. The opinions of two specialists were sought to be sure that the test was genuine.

\subsubsection{Post-test}

The second instrument that was employed in this investigation was a post-testing questionnaire. An additional post-test was provided to the study's participants after the semester. The goal of administering such a test was to determine the efficacy of the treatment, which was the application of ALM in the classroom to teach listening and communication skills. For the EG, a post-test was administered after 20 sessions of English instruction, which included listening and speaking activities, were completed. As a result, the pre-test was issued once more to acquire the comparison findings between the experimental and CGs concerning learners' "progress in hearing and speaking." This study made use of the same test two times, first as a pre-test and again as a post-test instrument. The time and quantity of items were the same between the pre-test and post-test, indicating no difference. The only difference between the post-test and the pre-test was that the questions and themes, and options were changed to eliminate the possibility of recalling answers from the pre-test. In addition to checking the validity of the pre-test, the teachers who validated the post-test also checked the reliability of the post-test, which was calculated through the use of inter-rater reliability and was found to be 0.846 .

\subsubsection{Questionnaire}

An attitudinal questionnaire (Haq, 2014) including 12 items was administered. It showed the students' and teachers' attitudes towards the application of ALM in teaching listening and speaking skills. This questionnaire was distributed among teachers teaching at high schools in Ahvaz. In this questionnaire, the various short questions were given so that the valuable opinions of the teachers about oral language and the role of ALM in teaching in the development of listening and speaking skills were collected. The questionnaire's validity and reliability had previously been surveyed; however, since the original questionnaire received some changes to meet the purpose of this study, the researchers followed the same steps adopted for validating the idiom test to ensure the validity of the instrument. The reliability of the questionnaire was determined through a detailed pilot study. To assess the validity of the questionnaire, the researchers asked those ten teachers who validated pre and post-test to pass their comments on the validity and content appropriateness of the questionnaire. Moreover, the reliability was obtained using the Cronbach alpha formula as it was 0.867 . 


\subsubsection{Data collection procedure}

To accomplish the purpose of the study, the following procedures were followed. At first, two groups of learners with the same range of language proficiency were selected through the administration of the Oxford Quick Placement Test. These two groups were randomly divided into experimental and CGs. As mentioned in previous sections, each group is composed of 39 learners. Next, both groups took a pre-test, an adapted form of Haq's (2014) test on listening and speaking, and was checked against validity and reliability measures. The test consisted of different items and topics, which asked the learners to listen and speak. The pre-test checked the participants' level of listening and speaking in both groups concerning the issues and activities which was going to be presented in 26 sessions of the classroom (taking place for a period of three months, including 13 weeks, and each week consisting of two 70- minute sessions). Afterward, the EG was taught through using ALM, and the CG, on the other hand, was taught via traditional approaches. Finally, the pre-test was repeated at the end of the study to guarantee the efficacy of the instructions and to measure students' improvement in listening and speaking during the research, hence the term "post-test" in this study. In addition, the questionnaire comprising twelve items was distributed among high school teachers to seek teachers' views and perspectives regarding the inclusion of ALM in teaching productive skills.

\section{Results}

\subsection{Test of Normality}

In data analysis, first of all, the normality of distribution was investigated. The results of the Kolmogorov-Smirnov test are presented in Table 1.

Table 1. Test of Normality

\begin{tabular}{llll}
\hline & \multicolumn{2}{l}{ Kolmogorov-Smirnova } & \\
& Statistic & df & Sig. \\
\hline EG. Listening Pre-test & .235 & 39 & .08 \\
Able 1CG. Listening Pre-test & .228 & 39 & .12 \\
EG. Speaking Pre-test & .195 & 39 & .07 \\
CG Speaking Pre-test & .167 & 39 & .09 \\
EG. Listening Post-test & .337 & 39 & .21 \\
CG. Listening Post-test & .195 & 39 & .23 \\
EG. Speaking Post-test & .237 & 39 & .07 \\
CG Speaking Post-test & .163 & 39 & .13 \\
\hline
\end{tabular}

Based on Table 1, the results show that the data distribution on the pre-test and post-test of both groups is normal ( $p>0.05$ ). It is, thus, safe to continue with parametric statistics.

\subsection{The Results of Both Groups' Speaking and Listening Pre-test}

Table 2 presents descriptive information about the speaking and listening pre-test of both experimental and CGs. It shows the descriptive statistics of groups on listening and speaking pre-test. The means of EG on the listening and speaking pre-test are 11.5897 and 12.2821, respectively. Moreover, the CG got mean scores of 12.0641 and 12.5385 on the listening and speaking pretest. It indicates that both groups were at the same level in the pre-test.

Table 2. Descriptive Statistics Comparing the Pre-Test of Both EG And CG Groups.

\begin{tabular}{llllll}
\hline & Groups & N & Mean & Std. Deviation & Std. Error Mean \\
\hline Listening Pre-test & EG & 39 & 11.5897 & 1.33215 & .21332 \\
& CG & 39 & 12.0641 & 1.46080 & .23392 \\
Speaking Pre-test & EG & 39 & 12.2821 & 1.82019 & .29146 \\
& CG & 39 & 12.5385 & 1.76361 & .28240 \\
\hline
\end{tabular}

However, to ensure any possible significant difference among these mean scores, independent samples t-test was run: 
Table 3. Independent Samples T-Test Comparing Participants' Performance on Listening and Speaking Pre-Test.

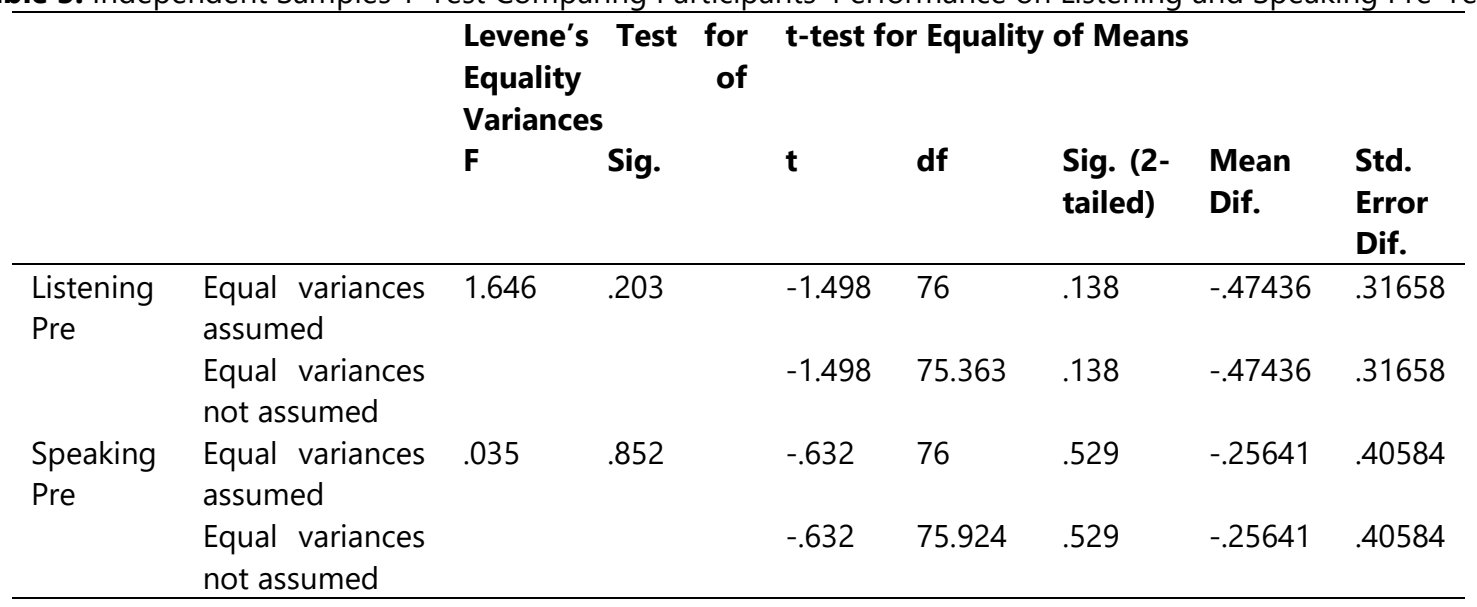

As shown in Table 3, regarding the mean scores of two groups on listening and speaking pre-test, no significant difference can be found since the significance level is greater than 0.05 . Therefore, it can be concluded that both groups had similar performances at the beginning of the study.

\subsection{Results for Research Questions One and Two}

A post-test of Speaking and Listening was administered to check if the treatment (teaching through ALM versus traditional instruction) significantly affects the groups' listening and speaking skills. The results of descriptive statistics of both groups' speaking and listening post-test are presented in Table 4.

Table 4. Descriptive Statistics Comparing the Post-Test of Both EG And CG Groups.

\begin{tabular}{llllll}
\hline & Groups & N & Mean & Std. Deviation & Std. Error Mean \\
\hline Listening Post & EG & 39 & 16.5385 & .64262 & .10290 \\
& CG & 39 & 12.5385 & 1.95133 & .31246 \\
Speaking Post & EG & 39 & 15.6923 & .89307 & .14301 \\
& CG & 39 & 12.6154 & 1.88994 & .30263 \\
\hline
\end{tabular}

Table 4 reveals the descriptive statistics of both groups on the speaking and listening post-test. The EG's mean score on speaking and listening post-test is 15.6923 and 16.5385, respectively, and the CG's mean score on speaking and listening post-test is 12.6154 and 12.5385, respectively. This means that the EG performed better than the CG on both speaking and listening post-test. To see if any significant differences can be found between the mean scores of both groups on speaking and listening post-test, an independent samples t-test was run. 
Table 5. Independent Samples T-Test Comparing Participants' Performance On Listening And Speaking Post-Test.

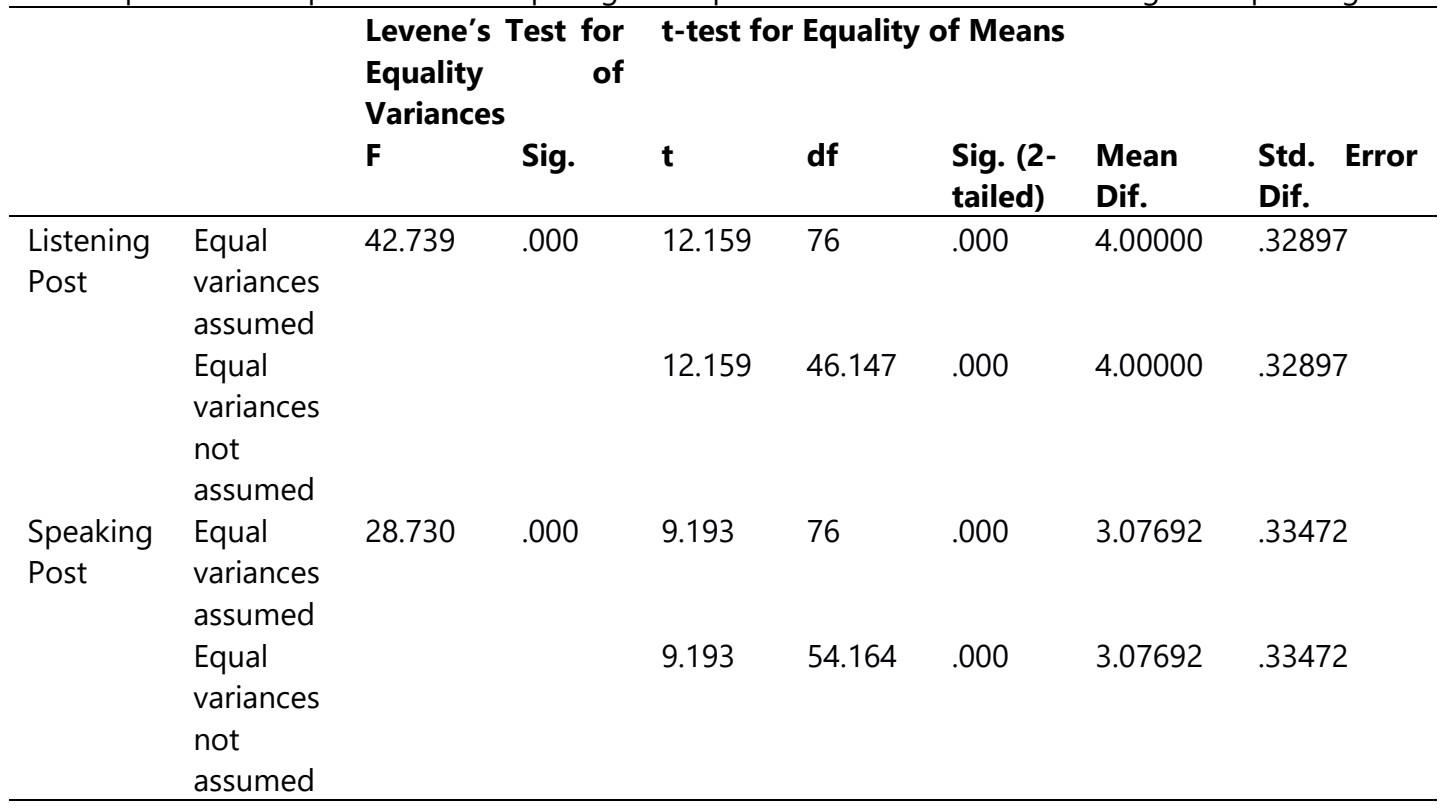

As shown in Table 5, the significance level is 0.000 , which means that the mean of listening and speaking scores in the experimental and CGs is not equal. Therefore, it indicates that the difference between both groups on post-test of listening and speaking is significant at $(p<0.05)$. The EG outperformed the CG on the post-test. Therefore, the first and second null hypotheses of the study are rejected, indicating that the implementation of the ALM has a significant impact on the listening and speaking skills of EFL learners, and those learners who taught listening and speaking through the ALM method performed better than those who are taught traditionally.

To further check if each group improved from pre-test to post-test, a paired t-test was used. The results of this test are presented in Table 6.

Table 6. Results of The Paired-Samples T-Test Comparing Pre-Test and Post-Test Scores Of The EG And CG.

\begin{tabular}{|c|c|c|c|c|c|c|c|}
\hline & & Mean & $\begin{array}{l}\text { Std. } \\
\text { Deviation }\end{array}$ & $\begin{array}{ll}\text { Std. Error } \\
\text { Mean }\end{array}$ & $\mathbf{t}$ & df & $\begin{array}{l}\text { Sig. (2- } \\
\text { tailed) }\end{array}$ \\
\hline Pair 1 & $\begin{array}{l}\text { EG. Listening Post - } \\
\text { EG. Listening Pre }\end{array}$ & 4.94872 & 1.39451 & .22330 & 22.162 & 38 & .000 \\
\hline Pair 2 & $\begin{array}{l}\text { EG. Speaking Post- EG. } \\
\text { Speaking Pre }\end{array}$ & 3.41026 & 2.07387 & .33209 & 10.269 & 38 & .000 \\
\hline Pair 3 & $\begin{array}{l}\text { CG. Listening Post - } \\
\text { CG. Listening Pre }\end{array}$ & .47436 & 1.45525 & .23303 & 2.036 & 38 & .069 \\
\hline Pair 4 & $\begin{array}{l}\text { CG. Speaking Post- } \\
\text { CG. Speaking Pre }\end{array}$ & .07692 & .26995 & .04323 & 1.780 & 38 & .083 \\
\hline
\end{tabular}

As shown in Table 6, the significant threshold for the EG performance on the pre-test and post-test of listening is 0.000 , which is less than 0.05 . This suggested that there was a substantial difference between the EG's mean listening pre-test and post-test scores. Moreover, since the Sig. is less than the .05, the difference between the speaking pre-test and post-test of the EG is also significant. It shows that the EG improved from pre-test to post-test on listening and speaking. So, these results imply that using ALM effectively affected the listening and speaking of the EG positively. So, instruction via ALM was influential in the EG. Considering the CG performance on pre-test and post-test of listening, the p-value is 0.069 , higher than 0.05 , indicating that there is not a significant difference between the mean of listening scores of pre-tests and post-tests in the CG. It can be concluded that the CG did not improve in listening from pre-test to post-test.

Furthermore, as the sig. is higher than .05, the difference between the speaking pre-test and post-test of the CG is not significant at $(p>0.05)$. The CGs did not improv in speaking from pre-test to post-test. This indicates that the treatment (using traditional instruction) was not practical so far as the speaking and listening skills of the intermediate EFL learners were concerned. 


\subsection{Results for Research Question Three}

The last objective of this study was to check if $\mathrm{L} 2$ teachers have a positive attitude towards using the ALM in teaching listening and speaking skills. Therefore, One-Sample Test was run.

Table 7. One-Sample Test (Teachers' Attitudes Toward Using ALM).

\begin{tabular}{lllll}
\hline & $\mathbf{t}$ & df & Sig. (2-tailed) & Mean Difference \\
\hline Attitude & 22.78 & 14 & .00 & 1.39 \\
\hline
\end{tabular}

It is seen in Table 7 that the teachers' attitude was significantly positive since the $p$-value was less than the significance level ( $p<$ .05). The teacher, thus, did welcome using the audio-lingual method for teaching speaking and listening skill.

\section{Discussion and Conclusion}

This study aimed to investigate the impact of ALM on the development of listening and speaking abilities among Iranian intermediate EFL learners. After evaluating the data, it was discovered that there was no statistically significant difference between the experimental and CGs, but there was a statistically significant difference between the post-test performance of the two groups. It can be concluded that the EG who received ALM instruction got better scores and outperformed the CG. ALM affected language learning positively. In the current study, ALM was used. It appears that individuals who concentrated on ALM learned more effectively than those who did not focus on it. Put another way; it will be more beneficial to use ALM to make the most of the instructional time available to gain as much knowledge as feasible. The results collected in chapter four demonstrate that employing ALM can improve students' listening and speaking abilities.

The reason that the students of the EG outperformed the CG is that the EG was taught through the ALM. At each session, they received input through the exercises which they practiced. The classroom's active atmosphere attracted the students' attention more and more; this made the experimental participants learn English better than the CG, which received no ALM. ALM plays a vital role in students' learning process, and this study may provide teachers with new insights on the method's importance and how to incorporate it into their teaching.

The results of this study are in line with Prayoga (2012), who investigate teaching listening skills using the audio-lingual method at first-grade students of the Asrama Bengkel Bahasa course. He concluded that teaching listening skills using ALM improved students' listening ability in the first grade of the Asrama Bengkel Bahasa Course.

The present study also supports the findings of Kunnu and Sukwises (2014), who taught speaking skills to adult English language learners through ALM. But their research was conducted on the assumption that ALM will resolve the problem of Thais who cannot communicate effectively in English. According to the findings of their study, participants can adjust their prior knowledge to practice conversational skills. As demonstrated in this experiment, people do not learn by imitation and repetition. Those who use them can elicit commonplace dialogue. Using what they have learned, the participants mimic the teacher. They pay close attention to what is being said in the discussion. Although Thais possessed essential English abilities, according to the author, they were incapable of communicating due to a lack of communication skills.

Students in the EG developed their listening and speaking thanks to receiving ALM instruction. Through the research, ALM was applied to the EG's classroom for ten weeks. When students attended the class, they were so active through practicing and dialogue and conversation, which helped them learn the materials effortlessly.

The EG that received listening and speaking instruction via ALM obtained higher scores than the CG, and their performance was superior to the CG as a result. Although all two experimental and CGs improved their results from the pre-test to the post-test, it is worth noting that the ALM instruction was found to be more successful than conventional instruction.

Concerning research question 3, the teachers' answers to the questionnaire were analyzed. Based on the results obtained (Table 7), most teachers preferred ALM because it helped the learners enhance their listening and speaking. Moreover, \% 95 of teachers approved that using ALM in the classroom helped them perform better in the post-test.

The teachers' agreement and acceptance may be due to some reasons. For the most part, they agreed that discussion is an effective method of introducing new material. A number of professors who supported the question believed that dialogues could give a natural framework for language forms, provided that they are derived from genuine communication rather than being intentionally presented in an artificial setting. It is also considered that dialogues reflect parts of the target language's cultural heritage. In addition, they can serve as excellent models of oral communication by demonstrating how language is employed in real-world interactions across different languages. The conversation is one aspect of dialogue, but it can also refer to a method of relating to others. In a small-scale communication process, individuals may say or hear something they have never said or heard before, and 
as a result of the process, they may emerge irreversibly altered. A focus on listening, learning, and forming common understandings are essential aspects of this method. Conversations help people better comprehend other points of view without having to pit themselves against opposing points of view in a debate. Furthermore, discourse fosters greater understanding and more innovative collaboration among individuals and organizations of different backgrounds and perspectives. Understandings and tensions will be reduced due to the process, and more fruitful interactions will be achieved in the future.

Teachers think that ALM offers a significant advancement in language education, as it is a methodology that is primarily concerned with communicative competency rather than linguistic proficiency. Generally speaking, a teacher who is adept at employing this strategy will be able to produce students who look to be highly "productive." The vast and sophisticated drills designed to help our learning and good "language habit formation" are new to the strategies used to practice the language. Many of them are vital components of "communicative" approaches that follow the ALM's guidelines.

The present study, which compared ALM versus conventional instruction in teaching listening and speaking skills, indicated that instructions play a vital role in learners' oral performance. Students struggle to communicate effectively in English and have difficulties speaking and listening; thus, educators should use the findings to provide their students with a more practical and effective teaching method, such as ALM. An excellent strategy for teaching and learning English, according to this research, is ALM. According to the findings of the t-test analysis, experimental students' speaking and listening abilities increased as a result of ALM. In contrast to the old method, it can be stated that the findings of this study proved the usefulness of ALM. In conclusion, the results of this study may be beneficial for students in terms of improving their communication and listening abilities, as the findings of this study verified the value of adopting ALM in the language learning process.

Because the research was successful, it is expected that English teachers will use any learning model and teaching aids, particularly ALM, to improve their students' listening and speaking skills and improve the overall quality of the teaching and learning process in their classrooms. Teaching this crucial language component in teacher-centered classes, where students play a passive role in learning, is a significant failing. Teachers fail to recognize the insight they can provide language learners by utilizing language learning methods in general and cognitive strategies in particular, resulting in a significant underestimation of the importance of this language component in teacher-centered classes. ALM plays a vital role in the learning process, and teachers can obtain insight into how to incorporate this method into their classrooms by reading the findings of this study.

Aside from that, the ALM also gives numerous valuable approaches for language instructors. Simply put, drilling approaches provide diverse, graded, and interview practice for specific aspects of the language through particular drills. Using a straightforward and straightforward method is particularly beneficial for younger students and those who are less talented. Speaking and listening skills are practiced through tape recordings and language lab drills, which are considered to be of major importance in learning a foreign language by experts. Furthermore, audio-lingual-based exercises can be adapted and used in conjunction with effect error correction techniques to create an approach that is sensitive to affective factors. This approach can then be followed up with strategies designed to encourage more independent experimentation and application of the information learned.

It also assists students who have difficulty communicating in both English and their native language, which the ALM provides. The use of a single-slot substitution drill and a transformation drill will help to reduce their issues, particularly in oral English, at the same time. Teachers must encourage students to overlearn to be able to employ grammar consciously and effortlessly when communicating in English. In light of the outcomes of this study, it is recommended that material designers create instructional materials based on ALM methods, particularly on the pictorial notion. The present study is also helpful for textbook designers since they can prepare materials that ALM can perceive.

\section{References}

[1] Bashir, M., Azeem, M., \& Dogar, A. H. (2011). Factor affecting students' English-speaking skills. British Journal of Arts and Social Sciences, 2(1), 34-50.

[2] Brown, G. (1994). Dimensions of difficulty in listening comprehension. In D. Mendelsohn \& J. Rubin (Eds.), A guide for the teaching of second language listening. (59-73). Dominie Press.

[3] Brown, H.D. (2001). Principles of Language Learning and Teaching. 3rd Edition. Eaglewood Cliffs.

[4] Crowl, K T. (1996). Fundamentals of Educational Research. Brown and Benchmark.

[5] Gilbert, J. (2008). Teaching pronunciation: Using the prosody pyramid. Cambridge University Press.

[6] Haq, H. (2014). An analysis of the effects of the Audio-Lingual Method of teaching on the listening \& speaking skills of students. International journal for teachers of English, 4(1), 2321-7170.

[7] Kunnu, W., \& Sukwises, A. (2014). Teaching speaking skills to adult English language learners through ALM. International Journal of Social, Behavioral, Educational, Economic and Management Engineering, 8(8), 2715-2718.

[8] Larsen-Freeman, D. (2000). Techniques and principles in language teaching (2nd 
edition). Oxford University Press.

[9] Lingzhu, J. (2003). Listening Activities for Effective Top-Down Processing. The Internet TESL Journal. http://www.iteslj.org/Techniques?lingzhu-Listening.html

[10] Mendelsohn, D. J. (1995). Applying learning strategies in the second/foreign language listening comprehension lesson. In D. J. Mendelsohn, \& J. Rubin (Eds.), A guide for the teaching of second language listening (132-150). Dominie Press, Inc.

[11] Namaziandost, E., \& Imani, A. (2020). Compensatory strategies and Iranian intermediate EFL learners' speaking fluency: focusing on selfrepetition and comprehension check strategies. International Journal of Linguistics, Literature, and Translation, 3(3), 107-114. Retrieved from https://al-kindipublisher.com/index.php/ijllt/article/view/1111.

[12] Namaziandost, E., Hashemifardnia, A., \& Shafiee, S. (2019). The impact of opinion-gap, reasoning-gap, and information-gap tasks on EFL learners' speaking fluency. Cogent Social Sciences 5(1), 1-16. https://doi.org/10.1080/23311886.2019.1630150

[13] Namaziandost, E., Homayouni, M., \& Rahmani, P. (2020). The impact of cooperative learning approach on the development of EFL learners' speaking fluency. Cogent Arts \& Humanities, 7(1).

[14] Namaziandost, E., Neisi, L., \& Banari, R. (2019). The impact of code-switching on vocabulary learning among Iranian upper-intermediate EFL learners. International Journal of Linguistics, Literature, and Translation, 2(5), 309-318. Retrieved from https://alkindipublisher.com/index.php/ijllt/article/view/603.

[15] Namaziandost, E., Shafiee, S., \& Ziafar, M. (2020). Investigating the impact of genre-based teaching (GBT) on intermediate EFL learners' listening improvement. Research in English Language Pedagogy, 8(2), 263-283.

[16] Nunan, D, (2005). Tasked-based language teaching. Cambridge University

[17] O'Malley, J. M., Chamot, A. U., \& Kupper, L. (1989). Listening comprehension strategies in second language acquisition. Applied Linguistics, 10 (4), 418-437.

[18] Prator, C.H. \&Celce-Murcia, M. (1979). An outline of language teaching approaches. In Celce-Murcia, M., and Mclntosh, L. (Ed.), Teaching English as a Second or Foreign Language (226-318). Newbury House.

[19] Prayoga, M. R. (2012). Teaching Listening Skill Using Audio Lingual Method at First Grade Students of Asrama Bengkel Bahasa Course. Siliwangi.

[20] Richards, J.C., \& Rodgers, T. S, (2002). Approaches and methods in language teaching. Cambridge Language Teaching Library.

[21] Shafiee, S., Mobini, M, Namaziandost, E., \& Ghodoosi, S. (2020). Contribution of multiple intelligences to L2 writing of EFL learners. International Journal of Linguistics, Literature, and Translation, 3(6), 59-69. https://doi.org/10.32996/ijllt.2020.3.6.7.

[22] Shakibaei, G., Shahamat, F., \& Namaziandost, E. (2019). The effect of using authentic texts on Iranian EFL learners' incidental vocabulary learning: the case of English newspaper. International Journal of Linguistics, Literature, and Translation, 2(5), 422-432. https://doi.org/10.32996/ijllt.v2i5.618

[23] Underwood, M. (1989). Teaching listening. Longman.

[24] Wang, Z. (2009). Modeling speech production and performance: Evidence from five types of planning and two task structures. (Doctoral dissertation). Chinese University of Hong Kong, Hong Kong.

[25] Ziafar, M., \& Namaziandost, E. (2019). Linguistics, SLA, and lexicon as the unit of language. International Journal of Linguistics, Literature, and Translation, 2(5), 245-250. 